\title{
Stańczycy - konserwatyzm, który przeminq̨t?, red. Jacek Kloczkowski, Ośrodek Myśli Politycznej, Kraków 2016, ss. 143
}

Na rynku księgarskim ukazała się książka pt. Stańczycy - konserwatyzm, który przeminąt? Została ona wydana przez Krakowski Ośrodek Myśli Politycznej, który od wielu lat stara się przypominać współczesnemu czytelnikowi osiągnięcia polskiej myśli konserwatywnej XIX i XX w., wydając nie tylko wybory pism postaci utożsamianych z nurtem konserwatywnym, ale również organizując konferencje i dyskusje. Ww. książka jest właśnie efektem jednej z konferencji, która odbyła się w Krakowie 12 X 2016 r. i była częścią projektu zatytułowanego Czego nauczyli nas Stańczycy. Program popularyzacji dziedzictwa polskiego konserwatyzmu w 150-lecie wydania pierwszego numeru "Przeglądu Polskiego”.

Książka została zredagowana przez Jacka Kloczkowskiego, natomiast autorami poszczególnych rozdziałów są znawcy myśli konserwatywnej, którzy z różnych perspektyw starali się odpowiedzieć na pytania zawarte w wstępie. Czy z punktu widzenia Polski czasów postańczykowskich można w ogóle mówić o tym, że ich idee polityczne odcisnęły znaczące piętno na życiu publicznym? Czy faktycznie ich myśl była takim przełomem w polskiej myśli politycznej? Jak Stańczyków można odnieść do nurtów konserwatywnych z innych państw? No i czy we współczesnych polskich realiach ma sens szukanie źródeł ideowych polityki w dziewiętnastowiecznej szkole politycznego myślenia, zarówno pod kątem faktycznego zerwania ciągłości lub kontynuacji polskiej tradycji politycznej, jak i - w tym drugim przypadku - sensowności prób reaktywowania starych szkół myślenia i adoptowania ich do zupełnie innych realiów?

Książka składa się z dwóch części. W pierwszej teksty autorstwa Krzysztofa Karola Daszyka, Dariusza Grzybka oraz Piotra Korysia dotyczą działalności stańczyków 
w kontekście czasów, w których przyszło im żyć i działać. Natomiast teksty Macieja Zakrzewskiego, Bogdana Szlachty i Rafała Matyji odnoszą się do dziedzictwa stańczyków i ich wpływu na kolejne pokolenia polskich konserwatystów. Są one próbą odpowiedzi na pytanie, w jaki sposób stańczykowski styl myślenia wpłynął na polską politykę po 1918 r. oraz co z ich spuścizny pozostało dzisiaj?

Książka ta jest efektem ożywienia w ostatnich latach badań nad polskim konserwatyzmem. Jest to publikacja o dziejach polskiej myśli konserwatywnej, ale także o ludziach z nią związanych. Już we wstępie Jacek Kloczkowski zwraca uwagę na sposób postrzegania tej grupy politycznej. Uważa, że choć stańczycy mieli jeden z najbardziej rozpoznawanych szyldów politycznych, w powszechnej świadomości społecznej, poza zawodowymi historykami, pozostają anonimowi. Kojarzy się ich zazwyczaj dość stereotypowo z negatywnym stosunkiem do powstań narodowych, a także z krytyczną oceną ustroju i praktyki Pierwszej Rzeczpospolitej czy jako zwolenników ugody z Habsburgami. Do tego dochodzą wątpliwości dotyczące zaliczania poszczególnych osób do tego grona. O ile nazwiska Stanisława Koźmiana, Stanisława Tarnowskiego, Józefa Szujskiego czy Ludwika Wodzickiego nie budzą wątpliwości, to „najbardziej rozpoznawalny” stańczyk, czyli Michał Bobrzyński, różniący się od swoich poprzedników zasadniczo w kwestiach myśli politycznej czy opiniach o historii Polski, już nie.

Pierwszy tekst zamieszczony w książce pod tytułem: Szkoła patriotyzmu politycznego. Stańczycy w autocharakterystyce autorstwa K. K. Daszyka to zwięzła historia „stronnictwa”. Autor podjął próbę zrekonstruowania dróg życiowych i prześledzenia intelektualnych inspiracji S. Koźmiana, S. Tarnowskiego, J. Szujskiego i L. Wodzickiego, nieco na drugim planie pozostawiając ideowo-polityczny wymiar ich działalności.

Autor swój tekst zbudował na wypowiedziach stańczyków o sobie samych, co pozwoliło w sposób interesujący ukazać ich aspiracje i odpowiedzieć na pytanie, za kogo się uważali i jaką rolę chcieli odegrać na narodowej scenie w okresie zaborów.

D. Grzybek podjął zaś próbę scharakteryzowania postaw konserwatystów krakowskich wobec modernizacji, tytułując swój tekst: Czy można być konserwatysta w zacofanym kraju? Wyobraźnia społeczna krakowskich konserwatystów. Charakteryzując sytuację społeczną i gospodarczą w Galicji autor uważa (nie bez racji), że pokolenie pierwszych stańczyków nie wypracowało programu społecznego i sugeruje, że nie byli oni nawet zainteresowani takim programem. Na dowód tego D. Grzybek podaje przykład wypracowanego przez konserwatystów z Klubu Konserwatywnego programu modernizacyjnego dla Galicji, który jednak został odrzucony przez 
większość konserwatystów. Warto przypomnieć, że podobny los spotka w dwudziestoleciu międzywojennym pomysły modernizacyjne Jana Bobrzyńskiego, który podobnie jak Jan Hupka czy Piotr i Antoni Górscy, nie bał się podejmować tematów społeczno-gospodarczych, widząc w tym jednocześnie szansę na zdynamizowanie obozu konserwatywnego i możliwość poszerzenia jego bazy społecznej. Te tylko dwa przypadki pokazują, że przywiązanie do zasad odziedziczonych po przodkach (koncepcja warstwy historycznej), tradycji oraz skłonność do korzystania z utrwalonych instytucji jest możliwa w krajach o stabilnym systemie politycznym i organicznym rozwoju społecznym. Natomiast w krajach „zacofanych”, jakim był Galicja, konserwatyści - aby nie ulec marginalizacji - musieli być po części rewolucjonistami.

Tematu modernizacji w myśli stańczykowskiej dotyczy również kolejny artykuł autorstwa P. Korysia zatytułowany Polityka nowoczesności w Galicji. Stańczycy wobec modernizacji. Autor rozpoczął swój tekst od wskazania osób mogących być wzorcem dla konserwatystów w przeprowadzaniu procesów modernizacyjnych w Galicji (Aleksander Wielopolski, Ksawery Drucki-Lubecki) podkreślając zarazem, że jako jedyne polskie ugrupowanie mieli oni legalny wpływ na politykę zaborców wobec ziem zamieszkałych przez Polaków. Autor zdaje się próbować w tekście odpowiedzieć na pytanie: czy stańczycy w ogóle dostrzegali potrzebę zmian społeczno-gospodarczych? A jeżeli tak, to jak chcieli ją przeprowadzić jednocześnie bez naruszania istniejących struktur społeczno-instytucjonalnych?

Przyczyn nastawienia antymodernizacyjnego stańczyków autor doszukuje się nie tylko w ich politycznych przekonaniach, ale po prostu $\mathrm{z}$ chęci obrony interesu stanowego, o czym świadczą słowa: „stańczycy w politycznej praktyce raczej zakonserwowali istniejący układ społeczny, niechętnie wspierając rozwój przemysłu, podtrzymując sytuację ekonomiczną wsi, korzystną zwłaszcza dla arystokracji i właścicieli ziemskich”. Niewielkie zainteresowanie kwestiami społeczno-gospodarczymi, zdaniem autora, wynikało z konieczności skoncentrowania się na celu nadrzędnym, jakim było nieistniejące państwo oraz z braku faktycznej możliwości wpływania na politykę rządu centralnego. Nawet jeżeli hasła modernizacji pojawiały się w wypowiedziach stańczyków, miały czysto deklaratywny charakter i nie towarzyszyła im skłonność do poważnych zmian.

Tekst M. Zakrzewskiego zatytułowany Konserwatyzm ofensywny. O Buncie Młodych (Polityce) i krakowskich konserwatystach, jest próbą pokazania tego co intelektualnie łączyło lub dzieliło pokolenie pierwszych stańczyków ze środowiskiem młodych mocarstwowców z dwudziestolecia międzywojennego. Autor uważa, że pomimo manifestacyjnego odcinania się młodych redaktorów „Buntu Młodych” 
od związków z konserwatyzmem, zwłaszcza tym sprzed 1918 r., przyjmowali oni postawę akonserwatywną, zachowując szacunek dla osiągnięć stańczyków. Ponadto pewne podobieństwa pomiędzy obydwoma środowiskami dostrzega w skłonności do unikania postaw radykalnych, podobnym katalogu wartości, ale przed wszystkim w byciu wiernym poglądom historycznej szkoły krakowskiej.

Autor słusznie zaznacza, że bliżej ideowo było grupie „Buntu Młodych” do M. Bobrzyńskiego niż S. Tarnowskiego, pokazując jednocześnie istnienie w obozie stańczyków dwóch nurtów, w ramach których kształtowała się ideologia stronnictwa.

Niektóre oceny i wnioski M. Zakrzewskiego skłaniają jednak do polemiki. W podsumowaniu zauważa on, że środowisko „Buntu Młodych” to de facto kontynuatorzy stańczykowskiej myśli politycznej. Czy aby na pewno? Prawdą jest, że odcinali się werbalnie od konserwatyzmu czerpiąc zarazem z jego tradycji. Zachowano polityczny styl myślenia. Ale na pewno „młodzi konserwatyści” nie byli obrońcami świętego ognia stańczyków, raczej rzecznikami metody konserwatywnej, którą stosowali poza doktryną. Ich twórczość nie miała świadczyć o żywotności tego kierunku ideowego - uważali oni bowiem, że konserwatyzm może się rozwijać poza sferą ziemiańską. Odrzucali twierdzenie, że zniknięcie tej warstwy musi prowadzić do obumarcia polityki konserwatywnej. Dlatego też z innymi obozami ideowymi szukali dla myśli konserwatywnej nowej bazy społecznej i nowych form organizacyjnych. Wprawdzie akcentowali przywiązanie do doktryny konserwatywnej podkreślając znaczenie religii, silnej władzy, misji polskiej na wschodzie Europy, ale często było to podejście instrumentalne, relatywizujące te wartości. Przestawały one być celem samym w sobie, jak to było w przypadku stańczyków, i stawały się środkiem realizacji wizji Polski mocarstwowej. Ich sposób myślenia pozwalał na przystosowanie się do określonych sytuacji politycznych. Elastyczność miała jednak swoje granice, których przejście oznaczało de facto odejście od konserwatyzmu. Moim zdaniem ta granica została przez „młodych konserwatystów” przekroczona. Jeśli jednak można mówić o myśli zachowawczej w ich wydaniu, to był to konserwatyzm względny, nie posiadający wszystkich właściwych cech specyficznych dla tego nurtu.

Ponadto stwierdzeniu, że „stańczycy stworzyli nowoczesną i ewoluującą wizję politycznego konserwatyzmu, alternatywnego wobec radykalizmu socjalnego i narodowego" przeczy ich niemal całkowita marginalizacja polityczna w początkach niepoległego państwa polskiego.

W tekście Wspominać stańczyków? w interesujący sposób B. Szlachta pokazał ponadczasową wartość stańczykowskiego stylu myślenia o zagadnieniach ustrojo- 
wych. Autor poddał analizie wybrane trzy zagadnienia (związek jednostki, grupy $\mathrm{z}$ władzą, istnienie ładu poprzedzającego działania prawodawcy, istota demokracji), którym zajmowali się stańczycy pokazując, że zarówno dzisiaj jak i w przyszłości istotą rozstrzygnięcia może być dostrzeżenie ich złożoności i uwzględnianiu licznych kontekstów.

Książkę zamyka artykuł R. Matyji zatytułowany Stańczycy bez spadkobierców. W tekście z jednej strony autor podkreśla znaczenie dorobku intelektualnego stańczyków i jego ponadczasowość, a z drugiej trafnie zauważa, że ich poglądy polityczne nie zostały poddane sensownej rewizji, co mogłoby je uchronić przed instrumentalizowaniem, a nawet zapomnieniem. Interesującą sprawą, którą autor omawia, są przyczyny renesansu myśli konserwatywnej na początku lat osiemdziesiątych XX w. Podkreśla, „że atrakcyjność intelektualna stańczyków nie polegała na tym, co było konserwatywne, lecz na tym, co sprzeciwiało się tradycji insurekcyjnej, romantycznym wzorcom myślenia o polityce”. W Trzeciej Rzeczypospolitej zaś żadna z formacji prawicowych nie odwoływała się do tradycji stańczykowskiej, nawiązując raczej do dorobku zachodnioeuropejskiej prawicy. Jedynym wartym odnotowania nawiązaniem przed 2007 r. było przywoływanie przez Partię Konserwatywną i Koalicję Konserwatywną postulatu siły państwa, autorytetu jego organów i równowagi między czynnikami demokratycznymi a elitarnymi.

Autor daje zaś czytelnikowi cenną wskazówkę, jak czytać dzisiaj stańczyków. Brzmi ona następująco: „Sądzę, że powinni być przede wszystkim traktowani jako szkoła myślenia krytycznego. Szkoła która nie wzięła się znikąd, ma swoje konserwatywne korzenie i praktyczne implikacje w polityce galicyjskiej, ale która może być czytana poza jednym i drugim kontekstem".

Publikacja Stańczycy - konserwatyzm, który przeminąt? może być ciekawą pozycją dla szerokiego grona czytelników zainteresowanych konserwatyzmem zarówno w aspekcie historycznym, jak i współczesnym. Artykuły w książce oparte są na fachowo przeprowadzonych badaniach, z wykorzystaniem bogatej literatury. Tezy i wnioski zostały sformułowane na podstawie gruntownej analizy i znajomości polskiej myśli konserwatywnej. Należy też powiedzieć parę słów o słabych stronach omawianej publikacji, których jest jednak niewiele. Poza nielicznymi polemicznymi ocenami i wnioskami, o których wyżej, problemem jest tytuł, który nie do końca jest adekwatny do zawartości. Z zamieszczonych sześciu zaledwie trzy artykuły nawiązują do tytułowego pytania. Nie zmienia to faktu, że książka może się okazać interesująca dla czytelnika i będzie ważnym elementem upowszechniania wiedzy o tradycjach polskiej myśli konserwatywnej. 
dr Sebastian Paczos

Instytut Historii

Wydział Historyczny

Uniwersytet im. Adama Mickiewicza w Poznaniu

ul. Umultowska 89d

61-614 Poznań

paczos@amu.edu.pl 